\title{
OUR PROGRAM.
}

\section{By J. W. Beach, Chairman, Buffalo, N. Y.}

The program for our second annual meeting to be held in Concert Hall, Hotel Astor, New York, on October 23 and 24 , is to be one of much interest and value to our members and to the profession at large. The sessions will be open to every one interested in the great work of the League and we are assured of an ample supply of "Glad Hands" which will be working every minute during the entire meeting.

We want every one of our members who possibly can do so, to visit New York at this time and we can assure them of a splendid time. Aside from the fact that there is only one greatest city on earth and that one is New York, we can promise you that this meeting of the National Dental Association is to be the greatest dental meeting that our profession ever has enjoyed.

The League will have a Preparedness Exhibit that will embrace everything in connection with its work and the army service of the dentist. Dental ambulances will be shown, all forms of outfits and equipment, different uniforms, significant of different ranks will be explained and representatives of the Surgeon-General will be present to give information and instructions relative to all military matters connected with the Officers' Reserve Corps, Dental Section.

Officers of the League will be in constant attendance to answer all questions and explain in detail everything in connection with our work and the official League button may also be secured.

The whole meeting will be distinctive in that the military atmosphere will impregnate every feature and more effectively than in any other way bring us to a fuller realization of our relations to the great work at hand and to the unquestioned importance of the service we must render our country and our fellowman.

COME because it is YOUR duty.

\section{7,005 MEN OF THE NATIONAL GUARD, NEW YORK, EXAMINED.}

July 18, 1917.

Dr. J. W. Beach,

Chairman Preparedness League of American Dentists, Buffalo, N. Y.

Sir: I am in receipt of the report of First Lieutenant Bissell B. Palmer, Jr., Dental Corps, covering the work performed by the dental profession of this State under the supervision of the Preparedness League of American Dentists, in furtherance of our desire to have the teeth of soldiers of the New York Division in proper condition for field service. What has been accomplished thru the practical patriotism of the dental profession is truly remarkable, and is quite beyond anything expected. The report shows that the teeth of 17,005 men of this Division were examined by members of the dental profession; that 10,032 teeth were extracted and 8,685 teeth filled. All this professional service and the materials used were furnished without expense to the State or Government, and they constitute a most valuable and substantial contribution to the cause.

Will you be good enough to make known in some way to those who have contributed to the above accomplishment the appreciation and thanks of the offcers and men of the New York Division?

Very respectfully,

(Signed) JOHN F. O'RYAN, Major General. 